\title{
Evaluation of Anti-inflammatory Effect of Oral Licorice in Comparison with Chlorhexidine in Population with Gingivitis: A Double Blind Clinical Trial Study
}

\author{
Oral Meyan Kökü Anti-enflamatuar Etkisinin, Diş Eti ilttihabı olan Popülasyonda Klorheksidin ile Karşılaştırılması: Bir \\ Çift Kör Klinik Araştırma Çalışması
}

\author{
Tahereh Molania ${ }^{1}$, Majid Saeedi ${ }^{2}$, Hodis Ehsani ${ }^{3}$, Zahra Khazaei ${ }^{4}$, Mahmoud Moosazadeh ${ }^{5}$, Sohrab Rostamkalaei ${ }^{6}$ \\ Mehdi Babaei Hatkehlouei ${ }^{7}$, Maede Salehi ${ }^{1}$
}

\begin{abstract}
${ }^{1}$ Department of Oral Medicine, Faculty of Dentistry, Mazandaran University of Medical Sciences, Sari, Iran
${ }^{2}$ Department of Pharmaceutics,Faculty of Pharmacy,Mazandaran University of Medical Sciences,Sari,Iran

${ }^{3}$ Department of Periodontology,Faculty of Dentistry,Mazandaran University of Medical Sceience,Sari,Iran

${ }^{4}$ Dentist, Tehran,Iran

${ }^{5}$ Health Sciense Research Center, Addiction Institude, Mazandaran University of Medical Sciences, Sari, Iran

${ }^{6}$ Department of Pharmaceutics,Faculty of Pharmacy,Mazandaran University of Medical Sciences,Sari,Iran

${ }^{7}$ Faculty of Dentistry, Mazandaran University of Medical Sciences, Sari, Iran
\end{abstract}

\section{ABSTRACT}

Background : Chronic gingivitis is the most pervasive gingival diseases that the main cause of it is microbe plaque. The best way to remove microbe plaque is mechanical methods. Chemical methods are supplementary to mechanical ones. Chlorhexidine is one of these ways but it has harmful effects. As in the past plants and herbs were very useful, nowadays they are used significantly. The present study aims at comparing the anti-inflammatory effect of two mouthwashes of licorice and chlorhexidine in patients with plaque-induced gingivitis.

Methods and materials: This study is done through double blind clinical trial. In which 75 participants who had gingival inflammation and were not sensitive to herbal mixtures with the age range of 20-40 were selected and randomly put in 3 groups of 25 people. The first group received licorice mouthwash $1 \%$, The second group chlorhexidine $0.2 \%$ and the third group were under placebo. For data gathering a checklist was used before and after the experiment and the data were analysed with spss 22 through Kruskal-Wallis and repeated measures ANOVA and Friedman.

Results: In investigating the plaque index in the first week of the study with licorice mouthwash there was no significant correlation with placebo but in the third week the correlation became significant. The study of gingival index between these two mouthwashes were reported significant in the first and third week. Comparing licorice and chlorhexidine in the first and third week there was no correlation in plaque and gingival index $(P$-value $<0 / 05)$.

Conclusion: Licorice mouthwash is effective in the treatment of gingivits. Although it is less powerful than chlorhexidine, It can be replaced by chemical drugs as it is very useful.

Key Words: Gingivitis, licorice, chlorhexidine, gingival index, plaque index

\section{ÖZET}

Amaç: Kronik diş eti iltihabı, asıl nedeninin mikrop plak olduğu en yaygın diş et hastalıklarıdır. Mikrop plakasını çıkarmanın en iyi yolu mekanik yöntemlerdir. Kimyasal yöntemler mekanik olanları tamamlar. Klorheksidin bu yollardan biridir, ancak zararlı etkileri vardır. Geçmişte bitkiler ve herbler çok faydalıydı, bugünlerde de önemli ölçüde kullanılmaktadır. Bu çalışma, plak kaynaklı gingivitli hastalarda meyan kökü ve klorheksidin ile iki gargaranın anti-enflamatuar etkisini karşılaştırmayı amaçlamaktadır.

Yöntemler: Bu çalışma, çift kör klinik çalışma ile yapılmıştır. İçinde diş eti iltihabı olan ve 20-40 yaş aralığında bitkisel karışımlara duyarlı olmayan 75 katılımcı seçildi ve rastgele 25 kişilik 3 gruba yerleştirildi. illk gruba meyan gargara \% 1, ikinci gruba \% 0.2'lik klorheksidin ve üçüncü gruba plasebo uygulandı. Verilerin toplanması için deney öncesi ve sonrasında bir kontrol listesi kullanıımış ve veriler Kruskal-Wallis ve SPSS 22 ile analiz edilmiş ve tekrarlanan ölçümlerde ANOVA ve Friedman kullanılmıştır.

Bulgular: Meyan indeksi araştırmanın ilk haftasında meyan gargara ile yapılan araştırmada, plasebo ile anlamlı bir korelasyon saptanmadı, ancak üçüncü haftada korelasyon anlamlı hale geldi. Bu iki gargara arasında dişeti indeksi çalışmasının birinci ve üçüncü haftalarda önemli olduğu bildirildi. Meyan kökü ve klorheksidinin birinci ve üçüncü haftada karşılaştırılması, plak ve dişeti endeksi ile korelasyon göstermedi $(P<0 / 05)$.

Sonuç: Meyan kökü gargara dişeti iltihabı tedavisinde etkilidir. Klorheksidinden daha az güçlü olmasına rağmen, çok faydalı olduğu için kimyasal ilaçlar ile değiştirilebilir.

Anahtar Sözcükler: Diş eti iltihabı, meyan kökü, klorheksidin, dişeti indeksi, plak indeksi

Geliş Tarihi: 07.04.2018

Kabul Tarihi: 03.06.2018 


\section{INTRODUCTION}

Gingivitis literally means gingiva inflammation and includes the most common gingival disease. Various research results indicate that microbial plaque is a major contributor to gingivitis, which is prevented by the removal of microbial plaques (1). Today, several ways to remove microbial plaque have been proposed, including mechanical and chemical methods. Evidence suggests that mechanical plaque control is not 100 percent effective in many people. As a result, attention has been paid to chemical plaque control methods (2). One can mention the chlorhexidine mouthwash which research shows that it has the best result on plaque (3). The most important side effect of chlorhexidine is the discoloration of teeth (4). The science of identifying and using medicinal plants is as old as human life. Until the 19th century, the use of natural resources was largely the main source of cure for diseases. But the rapid progress in chemistry and the lack of natural resources led to the replacement of new chemical compounds with herbal medicines. The antimicrobial, antifungal, and anticancer effects of Iranian herbs have been the source of many studies, and the outcomes of this research can lead to self-sufficiency and independence in the country's pharmaceutical industry. On the other hand, the bacterial resistance to chemically induced drugs requires the investigation and production of a variety of plant antimicrobials that seems logical (5). Glycyrrhiza glabra which is also called licorice (6) is one of the most important herbs in traditional medicine; it grows in different parts of the world and has been used for pharmaceutical purposes for at least 4,000 years. The roots of this plant have useful medicinal properties such as anti-inflammatory, antiviral, antimicrobial effects and it also has anticancer activity in addition to the activity of the immune system, hepatic and cardiac protection effects. It is a sedative plant that is useful in gastrointestinal disorders and oral ulcers (7). The roots of this plant were considered as an early drug for gastric ulcers until cimetidine emerged (8). The root of this plant contains Glycyrrhizin (13.6 to $63.3 \%$ ), flavonoids (5.1\%), comarin, alkaloids and polysaccharides, cytosterols and amino acids (9). Glycyrrhizin is a combination of sodium / potassium salts and Acid Glycyrrhizic which is known as the main anti-inflammatory component in this plant (7). Complications of this plant include edema, hypertension and hyperkalemia associated with glycyrrhizin and its derivatives. Known Flavonoids in this plant are active against Helicobacter pylori (10). This medicinal herb is found in Asia, the Mediterranean and some parts of southern Europe. This plant is considered as an anti-stress and anabolic agent. Licorice is prescribed after ginseng in China and is also used for the spleen, kidney and liver. The root of Licorice which contains glycyrrhizin is considered as the main source of water solubility and its sweet taste (11). In a study on the anti-inflammatory effects of Glycyrrhetinic acid, it has been mentioned that this plant inhibits the hydroxysteroid dehydrogenase enzyme - prevents the conversion of hydrocortisone to cortisone (non-active anti-inflammatory steroids) and its therapeutic effect is reflected in the target tissue (12). Therefore, considering the anti-inflammatory and pharmacological effects of this plant on wound healing and the lack of study on gingivitis, we decided to investigate the effects of this plant on gingivitis, which is an inflammatory process at Sari university 'Clinic. The aim of this study was to evaluate the anti-inflammatory effect of oral licorice in patients with gingivitis and to compare it with chlorhexidine mouthwash, when used alone.

\section{MATERIALS and METHODS}

This study was a randomized double-blind clinical trial study (IRCT2017043033722N1). The study population included patients with gingivitis referring to Sari Dental School in 2017 that were approved by a periodontist.

The criteria for entering the study included: People aged 20 to 40 years old, non-smokers, no systemic diseases or pregnancy, at least 24 teeth except third molar, no active caries, no antibiotic use during the past 3 months, gingivitis with a probe depth not greater than 4 milligrams, and ultimately ensuring of patient collaboration.
The results of the Begne study (13) were used to determine the sample size. Mean PI index in the study before intervention was $9.16 \pm 91.38$ and on the 14 th day it was $98.69 \pm 2.55$. Therefore, the sample size, taking into account these results, a $95 \%$ confidence level, a test power of $80 \%$, bidirectional test using the comparison formula between two means and Using G-power software was estimated to be 30 people ( 15 in the intervention group and 15 in the contro group). Considering the fact that in this study 3 groups were studied, using the following formula, the sample size was changed to 63 individuals ( 21 in the first intervention group, 21 in the second intervention group and 21 in the control group). Eventually, with a $20 \%$ reduction, it increased to 75 people ( 25 in the first intervention group, 25 in the second intervention group and 25 in the control group). At the time of entering the study, written consent was taken from patients, providing sufficient explanations to them.the number of samples were selected convenience sampling method and randomly were divided into 3 groups, the first group received $1 \%$ liquorice mouthwash, the second group received chlorhexidine mouthwash at a concentration of $0.2 \%$ and the third group received a placebo mouthwash. A checklist containing the demographic information of the patients, along with the date of the next examinations, the code of mouthwash and plaque index (plaque index = loe and silness index), and Gingival index (loose and silness index) was prepared and recorded for each patient in the first session. The examination was performed on Ramford teeth 3 $9,12,19,25$ and 28 . If one of these teeth was absent, side teeth were used. First, the teeth were dried and examined by a periodontologist using a probe, an explorer, and a mirror. To record the indexes, the gingiva of each tooth were divided into four levels of Dystofacial papilla, Mesiofacial papilla, facial margin and the entire lingual margin. According to Table 1 and 2 (14), each level has been rated. By dividing the total points of the four levels by four, gingival index and plaque index were obtained. Mouthwashes were available in dark colored bottles and similar to A, B and C codes. While the patient and the examiner did not know the contents of the mouthwash, each patient was given a mouthwash. The method of using mouthwash at $10 \mathrm{ml}$, twice a day (morning and evening) in combination with daily oral hygiene (brushing using the Bass method with whitening toothpaste) was taught to patients. Mouthwash should be gargled for 30 seconds and eating and drinking should be avoided for up to 1 hour after it. It was also emphasized to patients that mouthwash should be used regularly during 3 weeks of study. Follow-up sessions were performed in the first week and the third week after using mouthwash to record plaque and gingival index. Finally, the data entered the Spss 22 software. After refining the data, the normal distribution of variables was performed using the Kolmogorov Smear Nova test. Paired t-test, independent $\mathrm{T}$ test, Analysis of variance or their nonparametric equivalents, chi-square, were used. Comparison of the mean of the indices in different stages of measurement was performed by repeated analysis of variance and its nonparametric equivalent i.e. Friedman and post hoc test. The criterion for judging was a significant level less than $0.05 \%$.

Table 1: Loe and silness table for gingival index

\begin{tabular}{ll}
\hline Status & Score \\
\hline Normal gingiva & $\mathbf{0}$ \\
$\begin{array}{l}\text { Mild inflammation, slight discoloration, minor edema, no } \\
\text { bleeding at the touch }\end{array}$ & $\mathbf{1}$ \\
$\begin{array}{l}\text { Moderate inflammation, redness, edema and glazing , } \\
\text { bleeding in the touch } \\
\begin{array}{l}\text { Severe inflammation, the presence of edema and redness, } \\
\text { the tendency to self-hemorrhage }\end{array}\end{array}$ & $\mathbf{2}$ \\
\end{tabular}


Table 2: Loe and silness table for the plaque index

\begin{tabular}{|c|c|}
\hline Status & Score \\
\hline No plaque on tooth and gingiva surface & 0 \\
\hline $\begin{array}{l}\text { A thin shell of sticky plaque exists in the free gingiva } \\
\text { margin and adjacent tooth, and the plaque may only be } \\
\text { detected by moving from the root surface. }\end{array}$ & 1 \\
\hline $\begin{array}{l}\text { Moderate accumulation of soft sediments on the gingival } \\
\text { margin and adjacent tooth surface (visible by the naked } \\
\text { eye) with gingival envelope }\end{array}$ & 2 \\
\hline $\begin{array}{l}\text { Abundant soft materials on the gingival margin and } \\
\text { adjacent tooth surface with gingival envelope }\end{array}$ & 3 \\
\hline
\end{tabular}

Instruction for preparing mouthwash

In a one-liter beaker, 8 grams of licorice was weighed and solved it in $500 \mathrm{~g}$ of UP water and then, with a needle-free syringe, 4 grams of Tween 80 with 120 grams of glycerol was added to the licorice and UP water mixture, and then leaker was placed under electric stirrer with about 680 round for ten minutes in the next step, $174.4 \mathrm{~g}$ UP water was poured into a $250-\mathrm{ml}$ leaker and then we $440.1 \mathrm{~g}$ of methyl paraben was weighed and dispensed into leaker, then the leaker was placed inside Ben-Marie at $100^{\circ} \mathrm{C}$ until a clear and transparent solution was resulted after 10 minutes and the mixture was stirred by a mixer every few minutes, after dissolving, methyl Paraben and propyl Paraben added to the UP water placed inside Ben-Marie, a clear solution was resulted which was added to the leaker containing licorice in step one and was thoroughly mixed for about three minutes under an electric stirrer. The stirrer was switched off and the solution was dispersed from filter paper and after that the solution under the strainer was poured into the containers that were previously sterilized with $70 \%$ ethanol.

\section{RESULTS}

The mean and standard deviation of age in the liquorice group was $31.32 \pm 6.55$, in the chlorhexidine group $30.96 \pm 6.88$ and in the placebo group $30.6 \pm 6.83$. There was no significant difference in age between treatment groups $(P=0.958)$. In the liquorice group, 12 male and 13 female, in the chlorhexidine group, 14 were male and 11 were female, and in the placebo group, 10 were male and 15 were female. There was no significant difference between sexes in the studied groups $(\mathrm{P}=0.574)$.

In this study, the age-related p-value was 0.958 , which was not significant indicating the age balance between different groups of patients. The mean age of 25 recipients of licorice was 31/32 years, 25 recipient of chlorhexidine was $30 / 96$ years and 25 people receiving placebo was $30 / 60$ years.

Table 3: investigating Average plaque index in the study days by groups

$\begin{array}{lllllll} & \text { Placebo group } & & \text { Chlorhexidine } & \text { group( } & \text { Licorice } & \text { group } \\ \text { Plaque index } & ( & \text { Mean } \pm \text { SD) } & \text { Mean } \pm S D) & \text { (Mean } \pm S D) & \text { Intergroup P-value }\end{array}$

\begin{tabular}{|c|c|c|c|c|}
\hline $\begin{array}{l}\text { In th beginning of } \\
\text { the study }\end{array}$ & $0.2 \pm 1.74$ & $0.2 \pm 1.77$ & $0.2 \pm 1.74$ & 0.931 \\
\hline $\begin{array}{l}\text { The end of the first } \\
\text { week }\end{array}$ & $0.2 \pm 1.55$ & $0.2 \pm 1.42$ & $0.2 \pm 1.44$ & $0.048^{*}$ \\
\hline $\begin{array}{l}\text { The end of the third } \\
\text { week }\end{array}$ & $0.2 \pm 1.39$ & $0.2 \pm 1.07$ & $0.2 \pm 1.16$ & $0.001^{*}$ \\
\hline $\begin{array}{l}\text { intragroup } \\
\text { P-value }\end{array}$ & $<0.001^{*}$ & $<0.001^{*}$ & $0.001^{*}$ & \\
\hline
\end{tabular}

*Significant relationship: p-value $<0.05$

As seen in Table 3 In intra-group comparison, plaque index significantly decreased in all three groups $(P=0 / 001)$. The plaque index had the highest decrease in the end of the first week in the chlorhexidine group and then in the licorice group. The results of the study after 3 weeks showed that the maximum effect was significant for reduction of plaque index in the chlorhexidine group so that $\mathrm{PI}$ has reached from $1 / 77 \pm 0 / 2$ to $1 / 07 \pm 0 / 2(P<0 / 001)$. In comparison between groups, also, plaque index was significant between the treatment groups at the end of the first week and the third week $(\mathrm{P}=0 / 05)$ (Table 3, Figure 1)

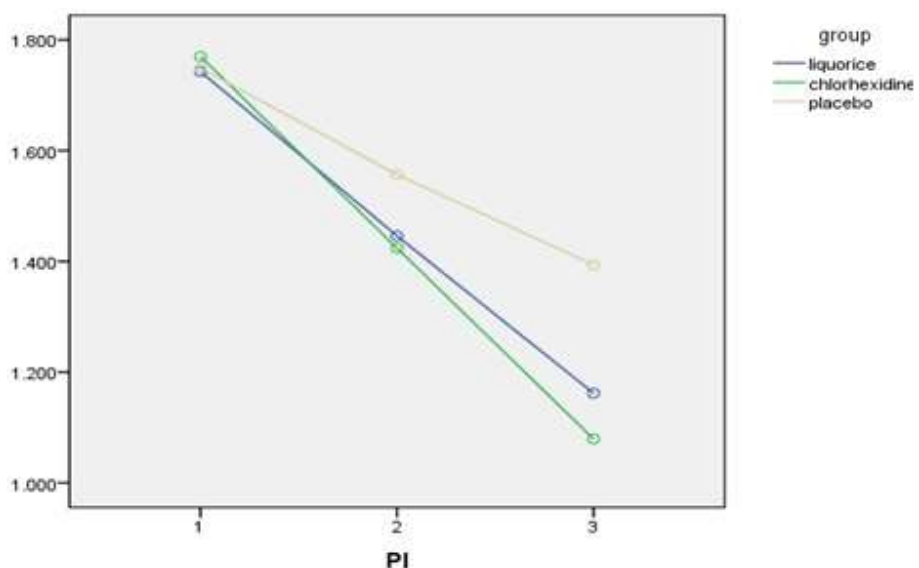

Figure 1: Evaluation of mean changes in plaque index at the moment of first and third visit in three groups 
To find out this difference was significant between which two groups of mouthwashes, we performed a post hoc test to compare the plaque index between two groups. The results showed that plaque index between two groups of licorice and chlorhexidine at the beginning of study was not significant. There was no significant difference between the two groups in the first week of study(p $=0.92)$. This insignificance was also observed at the end of the study $(p=0.396)$.
While comparing the plaque index, there was no significant statistical difference between the licorice group and the placebo group at the beginning of the study and the first week. Significant relationship was observed at the end of the third week $(P=0.001)$. There was no significant decrease in chlorhexidine mouthwash group during the first week compared to placebo group but at the end of the third week there was a significant difference $(p<0.001)$.

Table 4: Investigating the average gingival index in the study days by groups

\begin{tabular}{|c|c|c|c|c|c|c|}
\hline Gingival index & $\begin{array}{l}\text { Placebo group } \\
\text { (Mean } \pm \text { SD) }\end{array}$ & $\begin{array}{l}\text { Chlorhexidine } \\
\text { Mean } \pm \text { SD) }\end{array}$ & group( & $\begin{array}{l}\text { Licorice } \\
\text { (Mean } \pm S D)\end{array}$ & group & $\begin{array}{l}\text { intergroup } \\
\text { P-value }\end{array}$ \\
\hline
\end{tabular}

\begin{tabular}{lllll}
\hline $\begin{array}{l}\text { At the beginning of the } \\
\text { study }\end{array}$ & \pm 1.640 .3 & $0.2 \pm 1.61$ & $0.2 \pm 1.57$ & 0.639 \\
End of the first week & \pm 1.490 .3 & $0.2 \pm 1.27$ & $0.2 \pm 1.32$ & $0 / 003^{*}$ \\
End of the third week & $0.3 \pm 1.37$ & $0.2 \pm 0.96$ & \pm 1.030 .3 & $<0 / 001^{*}$ \\
intragroup & $<0 / 001^{*}$ & $<0 / 001^{*}$ & $<0 / 001^{*}$ &
\end{tabular}

P-value

Significant relationship: p-value $<0.05$

In the above table, it can be seen that in the intergroup comparison of gingival index, there was a significant difference between the three treatment groups during the study weeks. The gingival index decreased most in the chlorhexidine group and the lowest in the placebo group during the three weeks. At the end of the study, in an intergroup comparison, at the end of the first and third weeks, significant differences were observed between the groups (Table 4, Figure 2).

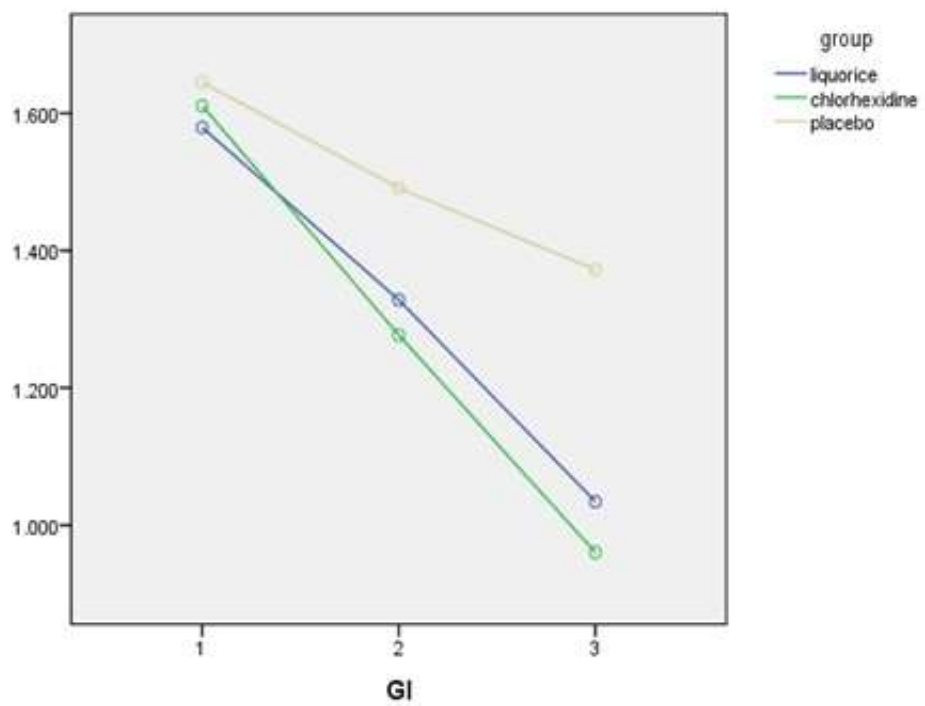

Figure 2: Evaluation of changes in mean gingival index at the moment of first visit and third week in three groups

The results of statistical analysis of post hoc test showed the relationship between groups as two to two. The relationship between chlorhexidine and licorice in the first week of study $(p=0.726)$ and also at the end of the study was not significant $(p=0.608)$. A significant relationship was observed between the two groups of licorice and placebo in the first week $(p=0.046)$ and at the end of the study $(P<0.001)$. The chlorhexidine mouthwash did not show a significant relationship with placebo in the first week $(p=0.06)$. But this mouthwash showed a significant relationship at the end of the study with placebo $(P<0.001)$.

\section{DISCUSSION}

This study was conducted to evaluate the effect of licorice herbal mouthwash and to compare it with chlorhexidine mouthwash. The study was performed on 75 patients ( 36 males and 39 females) patients with gingivitis referring to the dental clinic of Sari, without any history of systemic disease and allergy to licorice mouthwash compounds. 25 patients received $1 \%$ licorice mouthwash, 25 other patients received chlorhexidine mouthwash at a concentration of $0.2 \%$ and the third group of 25 patients received a placebo mouthwash. According to the results, it was observed that in the intragroup comparison the plaque index and gingival index were significantly decreased during the study in all three groups $(P=0 / 001)$. The plaque index in an intragroup comparison had the highest reduction in the chlorhexidine group and then in the licorice group at the end of the first week. The results of the study after 3 weeks showed that the highest reduction in gingival index occurred significantly in the chlorhexidine group. Gold standard treatment for gingivitis has been chlorhexidine for many years, and many studies have been conducted to confirm this $(15,16)$. Chlorhexidine has been less satisfactory for patients due to undesirable side effects, and this has led researchers to carry out research to compare it with herbal medicines. The results of the research on comparing the effects of chlorhexidine and herbal drugs on gingivitis show that all the studied herbal drugs, like chlorhexidine, can be effective in improving gingivitis, plaque and gingival index and improving oral hygiene (17-19). In the meanwhile, only one contradictory study was observed and this study was conducted in 2015 about the effect of toothbrush / aloevera wood extract compared to chlorhexidine on gingival index in patients with endotracheal tube. In this study, 76 patients with a tracheal tube aged 18-65 years were included. Gingival index was recorded before the intervention and recorded again after 4 days. In this study, although the gingival index improved in both groups, comparing the mean gingival index on the fourth day showed that the gingival index in the intervention group (Persica / Aloe Vera) was significantly lower than the control group (chlorhexidine) and had a greater effect on gingival improvement (20). The reason for this is that although chlorhexidine alone has a better effect than Persica and Aloe Vera, but due to the effect of persica and aloevera synergism together, their effect is better than chlorhexidine. There was no significant difference in plaque index compared to placebo in the first group compared to placebo, but in the third week of study, there was a significant difference $(p=0 / 001)$. In explaining this lack of significance in the first week it should be stated that it may have been due to proper mechanical hygiene in patients. The Willershausen study showed that simultaneous use of Paradontax mouthwash and the use of mechanical methods (toothbrushes and dental floss) would improve gingivitis (21).

In the present study, by giving an herbal mouthwash and simultaneously teaching oral hygiene to patients, reduction in the inflammation of the gingiva has been observed. In the present study, there was no significant relationship between the effect of chlorhexidine and placebo on the gingival index at the end of the first week, but at the end of the third week of study there was a significant relationship. In reviewing the gingival index significant relationship was found between the two groups of licorice and placebo at the end of the first and third week of study. In explaining this significant difference between the two groups in the first week it should be noted that early anti-inflammatory effect of licorice was better in gingival index compared to chlorhexidine and this effect was observed until the end of the third week. Another good result in this study is the lack of significant difference between the two groups of licorice and chlorhexidine in plaque index and gingival index, which confirms the antiinflammatory properties of licorice. 
Glycyrrhiza glabra, often called Licorice, is one of the most important herbs in traditional medicine that grows in different parts of the world and is used for medicinal purposes (7). Licorice has a warm and dry nature. It protects skin and gastric mucosa with its anti-inflammatory properties and acts like corticosteroid. If used with fennel seeds, it is also effective in treating bad breath. If using as a mouthwash, it prevents tooth decay and dry mouth (7). The plant's roots contain several compounds of the terpinone, flavonoids, isoflavonoid, hydroxycoumarin, sterol and some essential oils which its most important compound is called glycyrrhizin which contains sodium / potassium salts and glycyrrhizic acid (22). Glycyrrhizin is the most important natural sweeteners and is 50 times sweeter than sucrose (23). It has been proven that the protective effects of the plant on liver disorders, allergic diseases, inflammation and gastric ulcers are largely dependent on glycyrrhizin (24). This study confirms the anti-inflammatory effect of licorice, which is consistent with the present study. In a recent study by Jain et al. in 2017, the efficacy of licorice mouthwash was evaluated compared to chlorhexidine mouthwash $0.2 \%$ in subjects with plaque dependent gingivitis. This study was performed on 104 students aged 12 to 15 years with clinical signs of chronic plaque-related gingivitis without systemic disease. Students were randomly divided into two groups. To 52 of them, chlorhexidine mouthwash $0.2 \%$ was given and 52 others were given a licorice mouthwash. Both groups were asked to use $10 \mathrm{ml}$ of mouthwashes twice a day. Suitable hygiene education was provided to patients, and oral B toothbrush and Pepsodent toothpaste were used. PI and GI were recorded at the beginning of the study and then 4 weeks after mouthwash use. The results showed that both mouthwashes decreased plaque index, but chlorhexidine had a higher decreasing effect. The two mouthwashes also had a decreasing effect on Gl, which showed a better recovery in the second and fourth weeks than the first week. Comparison between groups showed that the effect of chlorhexidine on the plaque index is admirable, which is why it is still effective as a gold standard gel in the treatment of gingivitis (25). The differences in this study with the present study were that the study was double-blind, which would eliminate any induction or intentional deception and more precision is obtained in the results. But in the Jain study, Mouthwashes were given to people while being informed of their content. In our study, the oral hygeine education method was based on Bass but in this study, the type of oral hygeine education method has not been discussed. In the present study, we achieved a similar result in the 4-week study over the course of 3 weeks. In the present study, a placebo that has no effective substance has been used, which results in more precision and also proves the antiinflammatory effect of the licorice. In Jain's study, the concentration of licorice mouthwash hasn 't been mentioned. In a study by Edwards et al.in 1990, the antiinflammatory effects of glycyrrhetinic acid on skin inflammation were studied. According to the results of this study, the anti-inflammatory effect of glycyrrhetinic acid, which is the main component of licorice, was found to be due to inhibition of cortisol to cortisone (26). Mukherjee et al. examined the effect of $\mathrm{G}$. tabral extract in different doses on various gastric ulcers in the rats. They concluded that the herbal extract reduces gastric acidity and increases $\mathrm{pH}$, and the results of this study support the role of this plant in treating gastric ulcers (27). The two above-mentioned studies point to the anti-inflammatory effect of licorice, which confirms the current study. Goultschin et al. investigated the effect of glycyrrhizin added to toothpaste and its effect on reducing plaque and improving gingivitis in humans. The results of this study showed that Glycyrrhizin, which is the main saponin of licorice, had no significant effect on the reduction of plaque index and gingival index (28). These results are contradictory with the results of the present study and the expressed properties of licorice. This difference may be due to inappropriate glycyrrhizin concentration or chemical mismatch in the toothpaste containing anionic detergents and antibacterial surface agent. Regarding the insignificant relationship between licorice and chlorhexidine in this study, licorice can be considered as a suitable alternative for chlorhexidine.

\section{CONCLUSION}

According to the information obtained, it can be stated that both licorice and chlorhexidine mouthwashes are effective in improving gingivitis and plaque and gingival index and they are common mouthwashes and standard for the treatment of chlorhexidine gingivitis.
However, due to its side effects and changes in the color of the tooth, its unpleasant taste for patients, its contraindications, the cost-effectiveness of herbal mouthwash, and the fact that herbal mouthwashes are without complications, due to the small difference between the indices and considering that the improvement in plaque and gingival index in the chlorhexidine group was better than herbal mouthwash, it could be used as a suitable alternative for chlorhexidine.

\section{Conflict of interest}

No conflict of interest was declared by the authors.

\section{REFERENCES}

1.Lee J, Nho YH, Yun SK, Hwang YS. Use of ethanol extracts of Terminalia chebula to prevent periodontal disease induced by dental plaque bacteria. BMC Complement Altern Med. 2017;17:113. doi: 10.1186/s12906-017-1619-1.

2.Mamgain P, Kandwal A, Mamgain RK. Comparative Evaluation of Triphala and Ela Decoction With $0.2 \%$ Chlorhexidine as Mouthwash in the Treatment of Plaque-Induced Gingivitis and Halitosis: A Randomized Controlled Clinical Trial. J Evid Based Complementary Altern Med. 2016 Dec 8. pii: 2156587216679532 3.Forouzanfar A, Mokhtari MR, Kamalinezhad M, Babayian M, Tavakoli-Kakhki $\mathrm{M}$, Lotfalizadeh $\mathrm{MH}$. Evaluation of Toothpaste Containing Aqueous Saffron Stigma Extract on Gingival Indices in Patients with Marginal Generalized PlaqueInduced Gingivitis. Iran J Med Sci. 2016;41:S31

4.Christensen $\mathrm{G}$. In vivo assays for presence of gel in trays. Clin Res Assoc Newsl. 1989;13:2-3.

5. Haghighati F, Jafari S, BEYT EJ. Comparison of antimicrobial effects of ten Herbal extracts with chlorhexidine on three different oral pathogens; an in vitro study. 2003:132

6.Kenna Mc, Jones D.J., Hughes K. Botanical Medicines : The Desk Reference for Major Herbal Supplement. Second ed. New Delhi: viva books; 2008:65-73.

7.Nassiri AM, Hosseinzadeh $\mathrm{H}$. Review of pharmacological effects of Glycyrrhiza sp. and its bioactive compounds. 2008;(22): 709-24.

8.Conn JW, Rovner DR, Cohen EL. Licorice-induced pseudoaldosteronism: hypertension, hypokalemia, aldosteronopenia, and suppressed plasma renin activity. JaMa. 1968;205:492-6

9.Li J-y, Cao H-y, Liu P, Cheng G-h, Sun M-y. Glycyrrhizic acid in the treatment of liver diseases: literature review. BioMed research international. 2014:147-51.

10.Morris D, Davis E, Latif S. Licorice, tobacco chewing, and hypertension. New England Journal of Medicine. 1990;322:849-50.

11.Saxena S. Glycyrrihiza glabra: Medicine over the miilennium. Natural product radiance. 2005;4(8):358-9.

12.Schleimer RP. Potential regulation of inflammation in the lung by loca metabolism of hydrocortisone. Am J Respir Cell Mol Biol. 1991;4:166-73.

13.Begné MG, Yslas N, Reyes E, Quiroz V, Santana J, Jimenez G. Clinical effect of a Mexican sanguinaria extract (Polygonum aviculare L.) on gingivitis. Journal of ethnopharmacology. 2001;74:45-51

14.Newman MG, Takei $H$, Klokkevold PR, Carranza FA. Carranza's clinical periodontology: Elsevier health sciences; 2011:124-48

15. Becerik S, Türkoğlu O, Emingil G, Vural C, OeZDEMIR G, Atilla G. Antimicrobia effect of adjunctive use of chlorhexidine mouthrinse in untreated gingivitis: a randomized, placebo-controlled study. Apmis. 2011;119:364-72.

16.Corbet $E$, Tam J, Zee K, Wong M, Lo E, Mombelli A, et al. Therapeutic effects of supervised chlorhexidine mouthrinses on untreated gingivitis. Oral Diseases. 1997:3:9-18

17. SafarAbadi M, rezaei K, Ghaznavirad E. Comparing the effect of Echinacea and chlorhexidine mouthwash on oral health in patients hospitalized in intensive care units. cmja. 2012; 2 :222-34

18.Chhina S, Singh A, Menon I, Singh R, Sharma A, Aggarwal V. A randomized clinical study for comparative evaluation of Aloe Vera and $0.2 \%$ chlorhexidine gluconate mouthwash efficacy on de-novo plaque formation. Journal of International Society of Preventive \& Community Dentistry. 2016;6:251

19. Mehta S, Pesapathy S, Joseph M, Tiwari PK, Chawla S. Comparative evaluation of a herbal mouthwash (Freshol) with chlorhexidine on plaque accumulation, gingival inflammation, and salivary Streptococcus mutans growth. Journal of International Society of Preventive \& Community Dentistry. 2013;3:25

20.Rezaei S1, Rezaei K, Mahboubi M, Jarahzadeh MH, Momeni E, Bagherinasab M, Gaffari Targhi M, Memarzadeh M. Comparison the effect of Miswak/Aloe Vera \& chlorhexidine mouthwashes on gingival index in intubated patients cmja. 2015; 5 :1155-66. 
21.Willershausen B, Kasaj A, Sculean A, Wehrbein H. Influence of an Herbal Mouthwash on Inflammatory Changes of the Gingiva in Patients with Fixed Orthodontic Appliance. Periodontal Practice Today. 2004;1:255-62.

22.PDR for Herbal Medicines. 3th ed. Thomson PDR. Montvale. 2004: 876- 7.

23.Duke JA and Ayensu ES, 1985. Medicinal Plants of China Reference Publications.1985: 4-20.

24.Wang Z, Nishioka M, Kurosaki Y, Nakayama T, Kimura T. Gastrointestinal absorption characteristics of glycyrrhizin from glycyrrhiza extract. Biological and Pharmaceutical Bulletin. 1995;18:1238-41..
25.Jain $P$, Sontakke $P$, Walia $S$, Yadav $P$, Biswas G, Kaur D. Assessment of the efficacy of licorice versus $0.2 \%$ chlorhexidine oral rinse on plaque-induced gingivitis: A randomized clinical trial. Indian Journal of Oral Health and Research. 2017;3:15

26.Edwards C, Teelucksingh S. Glycyrrhetinic acid and potentiation of hydrocortisone activity in skin. The Lancet. 1990;336:322-3.

27. Mukherjee M, Bhaskaran N, Srinath R, Shivaprasad H, Allan JJ, Shekhar D, et al. Anti-ulcer and antioxidant activity of GutGardTM. 2010;48:269-74.

28.Goultschin J, Palmon S, Shapira L, Brayer L, Gedalia I. Effect of glycyrrhizincontaining toothpaste on dental plaque reduction and gingival health in humans. Journal of clinical periodontology. 1991;18:210-2. 